\title{
DESTINATION WEDDING \\ - POPULARITY AMONG YOUNG STUDENTS
}

\author{
URSZULA SZCZEPANIK, ${ }^{1}$ WOJCIECH WIESNER ${ }^{2}$
}

\author{
University School of Physical Education in Wrocław \\ ${ }^{1}$ e-mail: urszula.szczepanik@awf.wroc.pl \\ ${ }^{2}$ e-mail: wojciech.wiesner@awf.wroc.pl
}

\section{JEL CODES \\ KEYWORDS}

ABSTRACT

\section{$\mathrm{Z} 32, \mathrm{Z} 30, \mathrm{Z} 19$}

weeding tourism, destination weeding, honeymoon

Purpose. The aim of the study is to get to know young people's opinion about wedding tourism. Method. The study was conducted using a selection of Second Year Master's Degree students, studying Physical Education in Wroclaw, Poland, in the field of Tourism and Recreation. The data were obtained by the researcher by means of a diagnostic survey method with the use of a questionnaire to gather research material. 100 respondents were asked to complete the questionnaire which consisted of 19 questions.

Findings. 69 people responded and 31 did not respond to the question what the wedding tourism is. Out of 100 respondents, 26 participate in wedding destination in Poland, 93 did not attend any wedding destination abroad. Respondents who preferred wedding destination chose: Italy, Greece, Spain. Honeymoon travel is recognised as an important part as well. A large group of respondents (78\%) declared an organization of honeymoon trip.

Research and conclusions, limitations. Empirical studies only concern young Polish people and include only wedding tourism.

Practical implications. Diagnosing and partly predicting research of the level and nature of participation in wedding destinations make it possible to prepare an offer for young people.

Originality. The study of young people concerning wedding destination is conducted well. This phenomenon is increasingly popular, but not scientifically documented.

Type of paper. Paper presenting the results of empirical research.

\section{Introduction and literature review}

The aim of the study is to get to know young people's opinion about wedding tourism. Based on the definition of wedding tourism formed by UNWTO (United Nations World Tourism Organization), it can be said that wedding tourism is: "the total of travel activities for a young couple and their possible visitors to a place where no one intends to marry is a resident of a given region or resident, and the primary purpose of the trip is to marry" (UNWTO, 2015). Wedding 
tourism, also known as wedding-based tourism, is defined as international travel to get married or to celebrate the wedding (Durinec, 2013, p. 1).

However, such description is limited, since tourism is considered people's movement outside their usual environment to countries and places (UNWTO, 2015). This tourism definition has no particular indication that tourism is relevant solely to foreign locations. It means that tourism could occur in the home country of an individual, as long as they travel outside their regular environment. In terms of wedding tourism, domestic travellers with the purpose of getting married or celebrate their wedding are considered as an equal part of wedding tourism as international wedding travellers. Therefore the following definition provided by G. Del Chiappa and F. Fortezza (2015) is approved throughout the thesis, as it states that wedding tourism is "tourist flows that arise from the participation to a destination wedding that is held in a place that is different from where both the bride and groom's, or just one of them, live" (p. 412). However, this definition is not complete. It does not indicate honeymoon as a part of wedding tourism, while in reality, destination weddings and honeymoons are the main components of wedding tourism. Therefore, the thesis acknowledge that wedding tourism is a domestic or international travel of couples with a purpose to get married or celebrate the wedding.

Wedding is once-a-life event in people's life. You may find that people planning to marry want this day to be unforgettable, unique and not just for them but also for guests who will be honoured to attend the ceremony. Observing the speed of the emerging tourism market and finding new trends, wedding tourism has a chance of a dynamic increase in popularity. The success of wedding tourism continues to be propelled by a variety of emotional and economic factors. Over the past two decades, this part of industry has been booming. Weddings have become more prominent, both as social aspiration and as popular culture. Despite this, very little research has investigated this phenomenon.

By choosing a location for wedding, future spouses are driven by the motives that play an important role in their lives. These may be childhood dreams, returning to the roots, desire to experience something new, or to get to know a new culture and create unique memories. This is also benefited by tourism market organizations, drawing on the benefits of further development and increasing financial returns. The most important element, however, is the emotional sphere, which is often forgotten during the clutter of organization and planning.

Wedding tourism is an authentic and looming part of the tourism industry nowadays. Thanks to the wide availability of airfreight, couples in love can arrange their wedding anywhere in the world. The destination weddings gain more and more participants in the world. Tourism motivations are important factors in understanding people's behaviour in relation to a choice of destination, especially for the wedding market. Findings revealed that wedding destinations can be considered as a complex cluster of interrelated stakeholders; hence, a high degree of coordination and cooperation is needed for destination competitiveness. Further, results suggest that wedding destinations are currently opting for a product/service-oriented strategy with very little attention to a more appropriate experiential and emotional approach (Del Chiappa, Giacomo, Fortezza, Fulvio, 2015). 
In almost every culture, wedding is a significant life event which calls for celebration in a deeply personal and memorable way. People, place, and preparation are the foundation of the wedding, as couples design a ceremony that tells their story. While the motivations and preferences of each couple are very different, the deep longing to celebrate love in a special and lasting way is consistent across ages and cultures. Wedding tourism - travelling internationally for the purpose of getting married or celebrating a wedding (Acorn Consulting Partnership Ltd., 2008) has become increasingly popular in recent years (Major, McLeay, Waine, 2010). Weddings have become a commodity, providing opportunities for each host destination to market itself as a place where a special life event can be commemorated in an unforgettable way (Boden, 2001).

The wedding tourism market is comprised of destination wedding couples and their guests, as well as honeymoon tourists. The main market segments of weddings abroad can be divided into: first time marriages, re-marriages, same-sex marriages and commitment ceremonies and renewal vows (Major, McLeay, Waine, 2010). A large percentage of wedding tourists originate from the United States, the United Kingdom, Germany, Italy, France and Scandinavia. Among the most popular destinations for these tourists are Hawaii, the Caribbean, Mexico, Sri Lanka, the Maldives, Mauritius, Cyprus and Italy (Poon, 2009, p. 3). The countries that are most often chosen to host a wedding are countries with a warm climate, due to the fact that the weather is guaranteed. Also the paperwork usually is easy to fill and the staff is happy to host the ceremony.

Wedding tourism is one of the fastest growing industries over the whole tourism industry. According to Mintel (Mintel, 2010), a United Kingdom based provider of market research, one in five UK weddings takes place abroad. Between 2005 and 2010, number of weddings abroad increased by 27 per cent. The desire of honeymoon abroad has also been growing, as consumer preference research revealed that the percentage of consumers wanting to honeymoon abroad has risen from 57 per cent to 70 per cent in the period from 2008 to 2010 (Mintel, 2010). From 2002 to 2007 , overall growth in wedding tourism market was estimated to be approximately ten per cent annually, with an expectation for even higher growth rates in the period to follow (Poon, 2009). In the United States, one in ten weddings is a destination wedding, which is a massive increase over the last decade. $15 \%$ newlyweds spend two times more money on honeymoon than an average couple and three times more than an average tourist on holidays. The average amount is USD 4,466. In 2013 the International Hospitality and Tourism Management Conference (ICOHT) showed the results of wedding tourism growth in 75\% between 2007 and 2012. It is easy to notice that huge income from this market is obtained by tourism companies, decorators or transport. Therefore, contemporary wedding tourism is a positive incentive to surprise potential customers who are mostly young people leaving the traditional wedding party to the destination wedding (Proceedings of the $1^{\text {st }}$ International Conference on Hospitality and Tourism Management - 2013).

The organization of the wedding lasts all year round. The weddings abroad market not only contributes to the wedding specialists who organize the event, but also has a large impact on the transportation, accommodation, and food sectors (Major, McLeay, Waine, 2010, p. 251). Consecutively, wedding coordinating companies, airlines, cruise lines, hotel chains, resorts and other stakeholders are discovering that they can profit substantially by making destination weddings a part of their 
tourist offer. Destination wedding sector comprises out of various suppliers, including venue and accommodation providers, caterers, photographers, make-up and hair artists, as well as wedding planners and travel agencies that help to organize the celebration and honeymoon (Del Chiappa, Fortezza, 2015). While the financial impacts of a domestic wedding event are experienced for only a day or two, the contribution of destination weddings is prolonged through an extended stay. The high season lasts from May to October, a large number of couples decide to attend a wedding and honeymoon season. Duration of the honeymoon is 8 days, while the average tourist spends less than 7 days on holidays. Married couple adjusts to a common life with greater income to spend, but also with greater spending on travel and holidays. And it is worth to mention that recently emerging wedding tourism trend is still in its development phase compared to sea-sun-sand or cultural and heritage tourism segments.

Hence wedding tourism brings many development opportunities for wedding related businesses, the growing importance of the sector among such businesses could be confirmed by the establishment of annual Destination Wedding Planners Congress. The event is notably fresh, as the very first edition took place in Greece in 2014. Next year in 2018 it will take place in Los Cabos, Mexico. The Congress is aimed to provide the platform to meet new partners, such as venue and accommodation providers, as well as designers and entertainers (Destination Wedding Planners Congress, 2014). As destination wedding planners seek to expand their network of suppliers, it demonstrates a growing need for better service quality.

Wedding tourism is described quite freely through the literature in articles. This subsection has attempted to discuss the general theme of wedding tourism in Poland and abroad.

The study was conducted among the students of the Academy of Physical Education in Wrocław, in the Department of Tourism and Recreation of the second year of the Master's degree. The research questions were set to solve the problem, which was to help to determine the tourist wedding trends of young people.

\section{Methods}

The study was conducted among the students of the University School of Physical Education in Wroclaw, Poland, in the field of Tourism and Recreation, at their second year of Master's degree. The research questions were set to solve the problem that helps to determine the tourist wedding trends among young people.

The data obtained from the conducted research by means of a diagnostic survey method with the use of a questionnaire constituted research material. 100 respondents were asked to complete the questionnaire consisting of 19 questions. Each of the respondents completed the questionnaire in paper form, without communication with the researcher. The respondents completed the questionnaire anonymously and voluntarily. The maximum research group in one day was ten people. The study took part in the first quarter of 2017. The collected data were statistically processed in order to study respondents opinions on weeding destinations. 


\section{Results}

Results of the questionnaire survey.

50 respondents are in a relationship and 50 are single. Out of 50 respondents in the relationship, the largest group (62\%) is in the partnership, half of $32 \%$ of respondents is engaged, $2 \%$ is married.

69 people provided the answer, and 31 did not, to the question what the wedding tourism is. The most common definitions of wedding tourism are: honeymoon, wedding organization outside the place of residence, foreign trip in order to marry, combination of exotic wedding ceremony.

Have the participants participated in wedding tourism?

Most students did not participate in wedding tourism in Poland or abroad. Out of 100 respondents, 26 have participated in destination wedding in Poland. This may mean that most of the wedding ceremonies remain in the place of residence. The next argument for not participating in wedding tourism in Poland may be the costs incurred due to the event itself and the additional costs - transport and accommodation, if the couple is not able to guarantee them. 93 people have not attended the wedding destination abroad. This proves that this is not yet a popular form of wedding organization among young Poles. The financial issue is also essential. The next reason, very likely, is the distance. This kind of wedding tourism can be organized anywhere in the world, which sometimes requires the need for vaccination or physical and mental preparation.

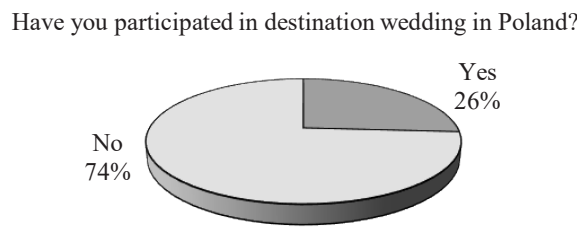

Figure 1. Participation in wedding destination in Poland among respondents

Source: own elaboration

Have you participated in destination wedding abroad?

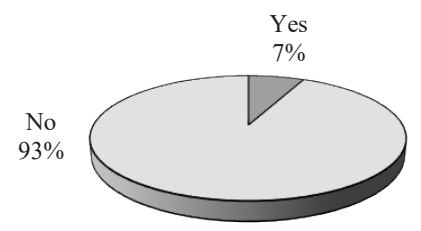

Figure 2. Participation in wedding destination abroad among respondents

Source: own elaboration. 
Are the students planning (dreaming of) a destination weeding?

The marriage contract in Poland has been declared by 74 persons, this means that respondents prefer a wedding within the country. 26 people have chosen a wedding ceremony abroad. The most frequently mentioned city was Wrocław, Poland, a place of residence of future spouses, as well as families and most of wedding guests. Other places of residence were often mentioned, which means a wedding in a hometown or a return to the roots was important sentimental issue. Fewer people have chosen foreign countries, which may indicate that these people prefer a more exotic, adventurous wedding in a newly perceived way. A pretty interesting result is about the honeymoon, as 78 people who expressed their desire to go on a honeymoon, 30 of them chose Europe, while results for Poland and also places outside Europe were evenly distributed, i.e. 24 people. Probably this choice is due to the availability of the offer, means of transport, and finance. The natural and cultural values that are available to visitors and the resting conditions offered by the resorts may also be a decisive factor. The other two extreme groups are Poland and abroad. The most likely conclusion regarding honeymoon in Poland is sentiment, willingness to stay in the country. Young people choose the country for financial reasons or for distance. An important element to make this decision, as well as decision to go abroad, is the time limitation. Traveling outside Europe can be determined by the desire to discover new places, cultures, customs, adventure experiences. This choice can be the only chance to go outside Europe, where young people often travel.

Respondents preferring wedding destination have chosen: Italy, Greece, Spain, Venice. One can see that these are very popular directions, so the respondents could follow their travels to these places, as well as the characteristics of the romanticism that prevails in these beautiful countries. The other places to be considered for the wedding are: sea, lakes and mountains. Such places can be determined by the atmosphere prevailing at the ceremony, the return to an important event that took place there or due to preferences of the newlyweds. The sea is the most frequently chosen place. Such a choice is, of course, with circumstances that add charm, perhaps it is also a sentiment for visited places or a relationship with an important event. Probably the reason is also the likeness of a young couple. Poland, Spain, Wrocław, Paris, Cracow became the next places - very well-known places that have beautiful history and beautiful sights. This choice is linked to the popularity of the tourists who frequent these countries and cities. Locations offer rooms and accommodation for a bride and a groom. Spain and France provide an opportunity to get to know a different culture and to encourage people to explore the natural and cultural values. Romanticism and the desire to experience an interesting experience contribute to fulfilling dreams. Wrocław and Cracow are the cities that reflect the history of Poland, which offers a wealth of historical monuments, as well as they provide for accommodation. The most attractive places and countries for wedding destination in respondents' opinion and the most attractive (unspecified) place for weeding destination are presented in Figure 3. 
Attractive wedding destinations (unspecified)

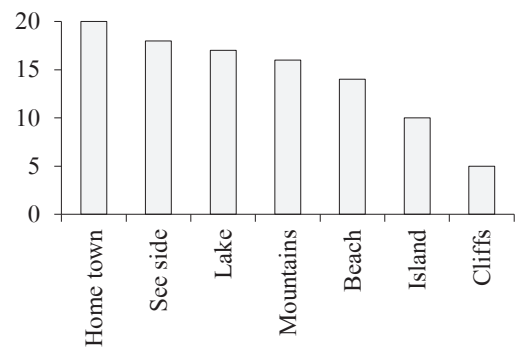

Attractive wedding destinations

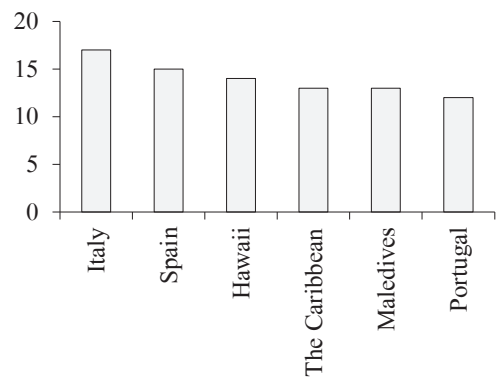

Figure 3. The most attractive places for weeding destination

Source: own elaboration.

The largest group of respondents (78\%) declared a honeymoon trip, then much less (14\%) did not plan a honeymoon, and $8 \%$ have not made a decision yet. Out of 78 people who have expressed their desire to go on a honeymoon, 24 prefer a honeymoon in Poland (12 - seaside, 8 - mountains, and 4 by the lake). Also, 30 have chosen their honeymoon in Europe (13 - seaside, 11 - mountains, 6 by the lake). Respondents indicated the most attractive countries (Maldives -17 people, Thailand and the USA - 15 people, Hawaii - 14 people, Italy - 12 people, Greece - 11 people, and 10 people - South America). Respondents selected the most attractive place to organize their honeymoon, mentioning the names of specific cities, such Wrocław (Poland) - 26, then 24 people chose Venice (Italy), 17 Paris (France), 14 Zakopane (Poland), 11 Cracow (Poland). The largest group (46 respondents) declared that the honeymoon should last for two weeks, while 31 chose a one-week honeymoon, evenly, 11 people - weekend and over two- week honeymoon trip.

The respondents were also asked what budget they could spend on wedding destination. The amount for the wedding ceremony ranges from PLN 100 to 100,000. Such a compartment may mean the possibility of the budget being collected by future young couples, a list of invited guests or expenses for particular wedding items. Respondents determine finances based on the type of ceremony: civil wedding, church wedding or other variants. As a result, the amount allocated is significantly different. The amount spent on honeymoon trip ranges from PLN 1,000 to 70,000. The range of the budget is undoubtedly dictated by the choice of place for the honeymoon, followed by a number of days, as well as a type of accommodation and transport. The honeymoon can also take place in the form of a tour around selected countries, offered by travel agencies or other institutions.

25 respondents declared wedding ceremony to be founded from own funds, 20 respondents indicated a loan, and the remaining 42 people indicated several sources of funding including: selfcontribution, credit and parents' money. It can be concluded that respondents themselves have their own budget and wish to organize this unique day according to their own preferences. Thus, while arranging a honeymoon, the respondents as a source of funding indicated: own contribution, credit, other variants and several variants. 


\section{Discussion}

The wedding tourism industry is evolving, as demand grows and consumer preferences change. Though it is a niche market itself, the sector has its own sub niche markets, creating opportunities for even more specializations among wedding tourism destinations. Thanks to wedding tourism in different regions of the country, young couples have a chance to learn about customs and traditions in places other than where they live, and use them on their most important day. Often these days, the ceremony is celebrated with old and new traditions, which are intertwined. In many parts of Poland the oldest traditions are practiced until today, some are even forgotten, but nevertheless, many honeymooners return to these customs. This form of tourism gives the opportunity to return to the oldest roots and to create a unique climate, which is sentiment to family habits. Wedding tourism is developing dynamically in the world, creating opportunities to get to know and benefit from the customs and traditions of other regions of the world. It can be said that the given tourism develops our interests and allows for our spiritual and intellectual development of the knowledge of a man and his worldview without giving up such an important institution as marriage.

Those who are going to marry want this day to be unforgettable, unique and not only for them but also for guests who will be honoured to attend the ceremony. All issues related to such an important undertaking are undoubtedly associated with large financial effort and huge amount of time devoted.

Travel agencies in order to keep up with new customer trends and expectations, are mobilizing to propose extreme and unforgettable events.

Poland could be also promoted as a quaint wedding destination. For foreigners, wedding ceremonies organized in Poland are an interesting alternative to their traditional form. Also our currency is often favourable to foreigners, so the organization of wedding ceremonies in Poland is cheaper than in other parts of Europe. For the Polish tourist wedding market could be increasingly important. Poland can be promoted as a perfect place for wedding or honeymoon for foreign guests. In Poland you may find variety of manor houses with beautiful gardens or decent palaces. This potential should be well utilized in the form of good advertising and promotion of Poland abroad and the opportunity for further development and financial gain. At the moment there is no statistical information on Poland as a destination for wedding.

However, it was found that very little research was conducted regarding the travel behaviours of wedding tourism. Few findings revealed that wedding tourists are primarily attracted by the destination's attributes such as famous "sea, sun and sand" which forms part of the characteristics of small tropical islands, followed by other pull attributes (Seebaluck, Munhurrun, Rughoonauth, 2015). The study from Mauritius confirms that destination managers should better understand travel motivations of tourists before developing and marketing product and services. Also studies in Malaysia confirm that the uniqueness of culture and a wedding venue is the main reason why these international bridal tourists choose Malaysia as a wedding destination (Zamri, Darson, Wahab, Lim, 2014). This study provides enormous benefits towards local event planners especially 
professional wedding planners, the potential of leveraging local resources as wedding tourism destination.

From the other hand couples are now seeking a celebration that is more extraordinary than the typical beach wedding (Major, McLeay, Waine, 2010, p. 252). Growing segments to target include the innovative weddings market, cruise weddings, the green weddings market, and gay and lesbian wedding tourism. There have been weddings on Table Top Mountain, on top of the Empire State Building, and even underwater. There has also been an increasing desire for 'White Weddings' in cold, snowy locations such as Iceland, Austria and Lapland (Major, McLeay, Waine, 2010, p. 255). Innovation in wedding tourism opens the market further, creating a place for destinations of varying climates and natural landscapes to profit from this market segment.

Besides, it is worth adding at the same time that marriage rates in twenty-first-century are historically low, divorce and separation are historically high, and marriage is no longer generally seen as a necessity for legitimate sexual relationships, long-term partnerships or even parenting (Carter, Duncac, 2017). Authors also emphasise that weddings are perceived as a social display of successes, emphasizing distinction, and manipulation by a powerful wedding industry. Interviewees in the research indicate four major discourses used to give meanings to their weddings: the project of the couple, relationality, re-traditionalization and romanticized consumption.

\section{Referenceses}

Acorn Consulting Partnership Ltd. (2008). Developing a niche tourism market database for the Caribbean. Retrieved from: http://www.onecaribbean.org/content/files/weddings.pdf (2.09.2017).

Boden, S. (2001). Superbrides: wedding consumer culture and the construction of bridal identity. Sociological research online, 6 (1). Retrieved from: http://www.socresonline.org.uk/6/1/boden.html (3.09.2017).

Carter, J., Duncan, S. (2017). Wedding paradoxes: individualized conformity and the 'perfect day'. Sociological Review, 1 (65), 3-20.

Del Chiappa, G., Fortezza, F. (2015). Wedding-based tourism development: insights from an Italian context. Marketing Places And Spaces, Book Series: Advances in Culture Tourism and Hospitality Research, 10, 61-74.

Durinec, N. (2013). Destination wedding in the Mediterranean. Development, trends, marketing. Paper presented at International Conference on Hospitality \& Tourism Management, Colombo.

Major, B., McLeay, F., Waine, D. (2010). Perfect weddings abroad. Journal of Vacation Marketing, 3 (16), $249-262$.

Mintel Reports (2010). Weddings and honeymoons abroad-UK. Retrieved from: http://oxygen.mintel.com/display/479945. Proceedings of the $1^{\text {st }}$ International Conference on Hospitality and Tourism Management - 2013 The way forward to tourism. ICOHT - 2013; http://tiikm.com/publication/ICOHT-2013-proceeding-book.pdf (1.09.2017).

Poon, A. (2009). Prospects for the British market. Tourism Industry Intelligence, 1 (16), 1-4.

Seebaluck, N.V., Munhurrun, P.R., Naidoo, P., Rughoonauth, P. (2015). An analysis of the push and pull motives for choosing Mauritius as "the" wedding destination. Book Series: Procedia Social and Behavioral Sciences. Proceeding of the $3^{\text {rd }}$ international conference on strategic innovative marketing (IC-SIM 2014), Volume: 175, 201-209.

UNWTO (2015). Understanding tourism: Basic glossary. Retrieved from: http://media.unwto.org/en/content/understanding-tourism-basic-glossary (7.09.2017).

Zamri, M.H., Darson, M.D., Wahab, M.F., Lim, L.K. (2014). Malaysia as a wedding destination: Perception and destination characteristics. Hospitality and tourism: synergizing creativity and innovation in research (pp. 381-384). 


\section{TURYSTYKA WESELNA \\ - POPULARNOŚĆ WŚRÓD MŁODYCH WROCŁAWIAN}

SŁOWA KLUCZOWE

STRESZCZENIE turystyka weselna, turystyka ślubna, podróż poślubna

Cel. Poznanie wiedzy i opinii młodych wrocławian na temat turystyki weselnej (destination wedding).

Metoda. Badania przeprowadzono wśród studentów Akademii Wychowania Fizycznego we Wrocławiu (Polska), kierunku Turystyka i Rekreacja drugiego roku studiów magisterskich. Wykorzystano metodę badań diagnostycznych z wykorzystaniem kwestionariusza. 100 respondentów zostało poproszonych o wypełnienie kwestionariusza składającego się z 19 pytań.

Wyniki. 69 osób odpowiedziało, a 31 nie odpowiedziało na pytanie, czym jest turystyka ślubna. Spośród 100 respondentów 26 brało udział w turystyce weselnej w Polsce, 93 nie brało udziału w turystyce weselnej za granicą. Respondenci pytani o preferowane kierunku dla turystyki weselnej wskazywali najczęściej: Włochy, Hiszpanię, Grecję, Hawaje. Wyjazdy dla nowożeńców są również uznawane za ważną część turystyki weselnej. Duża część respondentów (78\%) zadeklarowała uczestnictwo w podróży poślubnej.

Ograniczenia badań i wnioskowania. Badania empiryczne dotyczą wyłącznie młodych Polaków i obejmują wyłącznie turystykę weselną.

Implikacje praktyczne. Diagnozowanie i częściowe przewidywanie poziomu i charakteru uczestnictwa w turystyce weselnej umożliwia przygotowanie oferty dla młodych ludzi.

Oryginalność. Badanie młodych ludzi dotyczące turystyki weselnej przeprowadzane są w Polsce bardzo rzadko. Zjawisko to jest coraz bardziej popularne, ale nie udokumentowane naukowo.

Rodzaj pracy. Artykuł prezentujący wyniki badań empirycznych. 